\title{
Application of Analytical Hierarchy Process (AHP) Method in Determining Dike Construction for Handling Tidal Flood
}

\author{
Henny Pratiwi Adi ${ }^{1 *}$ \\ ${ }^{I}$ Civil Engineering Department of Sultan Agung Islamic University, Jl. Raya Kaligawe Km. 4 Semarang, \\ Indonesia \\ *Corresponding author: henni@unissula.ac.id
}

(Received: October 28 ${ }^{\text {th }}, 2019$; Revised: March 20 ${ }^{\text {th }}, 2020$; Accepted: March 23 $\left.3^{\text {rd }}, 2020\right)$

\begin{abstract}
Tambak Lorok in Semarang is one of the areas that often undergoes tidal floods. The construction of dam and dike infrastructure is an effort to overcome tidal floods. As one part of the flood control system, the dike has an important role. The construction projects requires an alternative selection method of dike construction in order to function optimally. This research aims to determine the order of priority criteria and alternative construction of dikes. The data were obtained through questionnaires to experts in the field of dike construction. The aspects of criteria used to analyze alternative dike construction are : functions and benefits, site conditions, costs and construction implementation. The dike construction alternatives include a Concrete Sheet Pile (CSP), Parapet Wall with reinforced Corrugated Concrete Sheet Pile/CCSP and landfill with Geotube Components. The questionnaire were processed using the Analytical Hierarchy Process (AHP) method with the Expert Choice v.11 application. The results showed consistency ratio (CR) of $5 \%$, which means that research data were consistent and could be accounted for. Based on weighting in pairwise comparisons, the priority criteria in selecting type of dike construction are : functions and benefits $(33 \%)$, site conditions $(32 \%)$, cost $(18 \%)$ and construction implementation $(17 \%)$ The priority alternative dike construction is reinforced Corrugated Concrete Sheet Pile/CCSP (39.7\%), landfill with geotube components (3.28\%) and Cylindrical Concrete Piles (CSP) (27.5\%). Dike construction with reinforced CCSP is a top priority in the handling of tidal floods in the Tambak Lorok area of Semarang due to its function and benefit aspects as well as the most suitable location conditions.
\end{abstract}

Keywords: tidal flood; dike; criteria; alternative

\section{Introduction}

Semarang is one city in Central Java located in the northern coastal region. The topographical condition of Semarang with a coastline of approximately $13.6 \mathrm{~km}$ often results in floods due to rising sea levels. One area in Semarang that experiences tidal floods is Tambak Lorok area [1]. The construction of dam and dike infrastructure is one of the efforts in overcoming floods and tides. In general, a dike serves to prevent floods on protected plains. In planning and designing a dike, there are several aspects that need to be considered to suit the function of flood prevention needs, technical requirements and aesthetics. These aspects are, such as, functions and benefits, site conditions, type of construction, construction costs, and work implementation [2].

The beauty and attractiveness of architecture need to be considered in designing a dike adapted to the function and construction model. There are several types of dikes that can be implemented to support tidal flood mitigation efforts, namely the dike with reinforced Concrete Sheet Piles (CSP), dike with parapet walls and Corrugated Concrete Sheet Piles (CCSP), and landfill dike with Geotube components [3]. 
Dike designing in the construction of flood control infrastructure plays an important role in determining the form of construction and its function, which is an important factor in managing coastal areas as the center of livelihood of local fishermen [4]. Therefore, it is necessary to have several structural design choices that serve as a reference in determining the right design, both in determining variations in shape, technician, function, as well as the balance of the aesthetic form. Thus, a decision support system is needed to choose the best alternative from several assessment criteria. This research aims to obtain priority order criteria and alternative construction of dikes using the Analytical Hierarchical Process (AHP) method.

\section{Literature Review}

\subsection{Dike Construction}

A dike is a construction made to prevent floods on protected plains. Dike construction is one of the engineering designs to meet human needs [2]). The dike is a retaining wall used to manage the water surface. It is usually made of concrete or stone pairs and most are built parallel to the river or beach by digging trenches and forming landfill on it. The main purpose of constructing a dike is to anticipate the occurrence of puddles on the plain on the riverbank [5]. This dike is very important because in some places the river water level is often higher when the flood is higher than the surrounding area. Dikes can also be found along the beach, where the sand piles of the beach are not sturdy enough to withstand the pounding of the waves. Dikes can also be built along the shores of a lake or beach as a protective boundary for a flooded location. Dikes can be either temporary or permanent construction, depending on the state of the water surface around the flooded area [6].

\subsection{Types of Dike Construction}

\subsubsection{Dike with Reinforced Concrete Sheet Pile (CSP)}

The main material of this dike is in the form of concrete sheet piles (CSP) which are reinforced with landfill on the sides of the land. Structurally, this type of dikes with CSP functions as a (sea) water pressure barrier as well as a retaining wall with a high enough cliff. This construction is in the form of precast concrete with a diameter of $1,200 \mathrm{~mm}$ with a thickness of $150 \mathrm{~mm}$ and the quality of concrete reaches $\mathrm{K}-800$ ([7].

This dike construction consists of several materials, namely:

1. The main material is a concrete sheet pile (CSP)

2. Landfill

3. Paving blocks at the top of the dike (if needed for the road)

Sections and visualizations for dike types using reinforced CSP can be seen in the following figure.

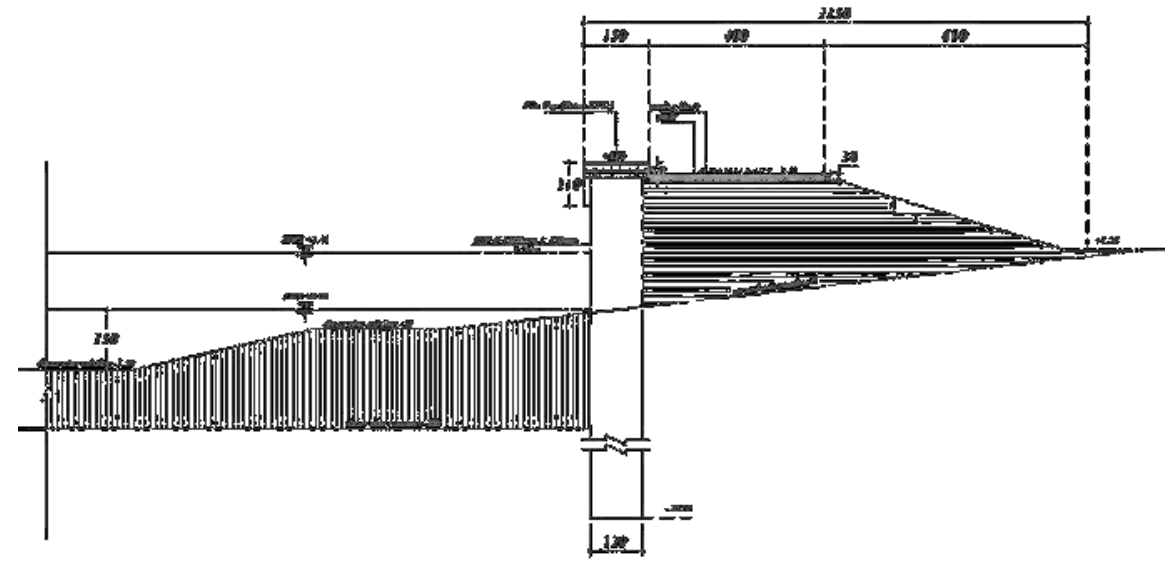

Fig.1. Cross section of Dike Type Using Reinforced CSP [6] 


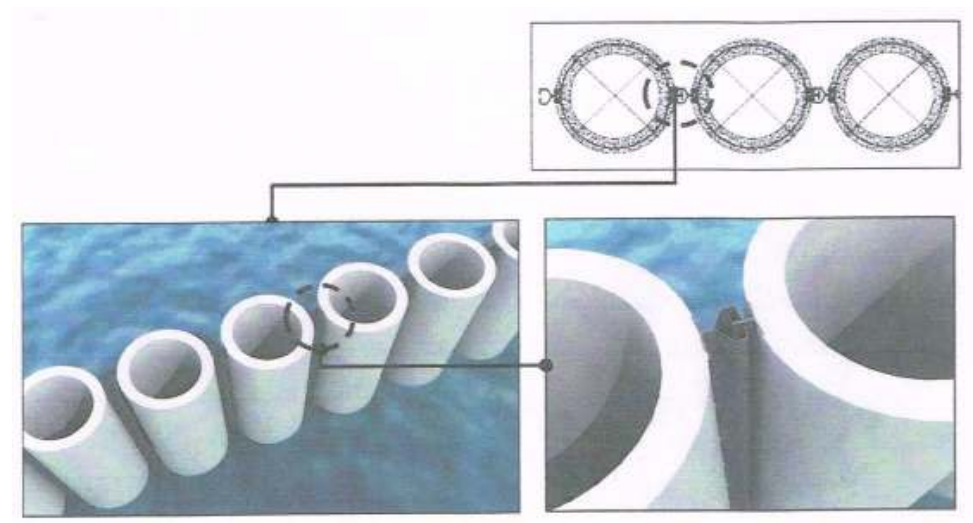

Fig.2. Concrete Sheet Pile (CSP) Arrangement

\subsubsection{Parapet Walls and Reinforced Corrugated Concrete Sheet Pile (CCSP)}

The main materials of this dike consist of :

1. Corrugated Concrete Sheet Pile (CCSP) mounted at the bottom (grooves) as a retaining wall for riverbank reinforcement (grooves)

2. Parapet walls are installed at the top to hold the high tide

Sections and visualizations for the dike types using parapet walls and CCSP reinforcement can be seen in the following figure.

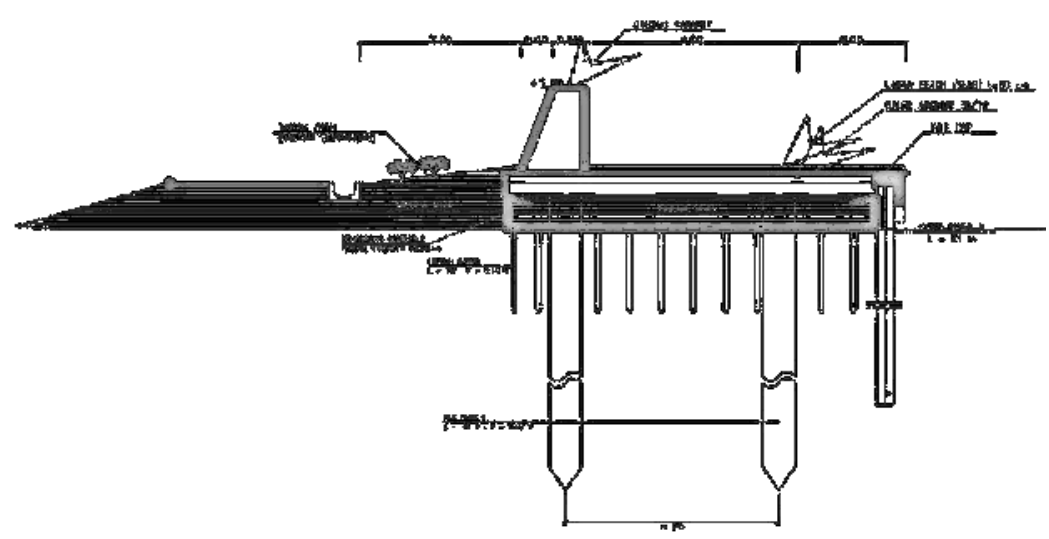

Fig. 3. Parapet Wall and Reinforced Corrugated Concrete Sheet Pile (CCSP) [6]

\subsubsection{Landfill Dike with Geotube Components}

This type of dike construction is very suitable to be applied in coastal areas that have soft soil conditions and directly borders with sea water. The dike with Geotube components is a construction in the form of a large pipe sheath filled with sand or soil material in it. Material filling is carried out by pumping. The material is made from geotextile (high strength geotextile) with certain specifications ([8]. Furthermore, the entire cross section of the dike is protected on the outside with a waterproof layer in the form of geosynthetic clay liner and a protective layer in the form of rip-raps to maintain security from the influence or activity from outside such as fishing, boat mooring and so on. The construction of this dike is relatively easy and requires a faster implementation time so that it can save costs or be cheaper [9]. This dike construction consists of several materials, namely:

1. Land/sand fill (selected material) for the main (core) material,

2. Geotube which is a geotextile material (high strength geotextile),

3. Geosynthetic clay liner for waterproof layer, 
4. Ripraps for protective layer (protection) against influence/activity from outside which can damage the geotube components,

5. Bamboo stakes to increase the carrying capacity of the foundation,

6. Thickness of grass for the protected layer on the back (land side),

7. Paving blocks at the top of the dike (if needed for the road),

The following is a section for the type of landfill dikes with Geotube components.

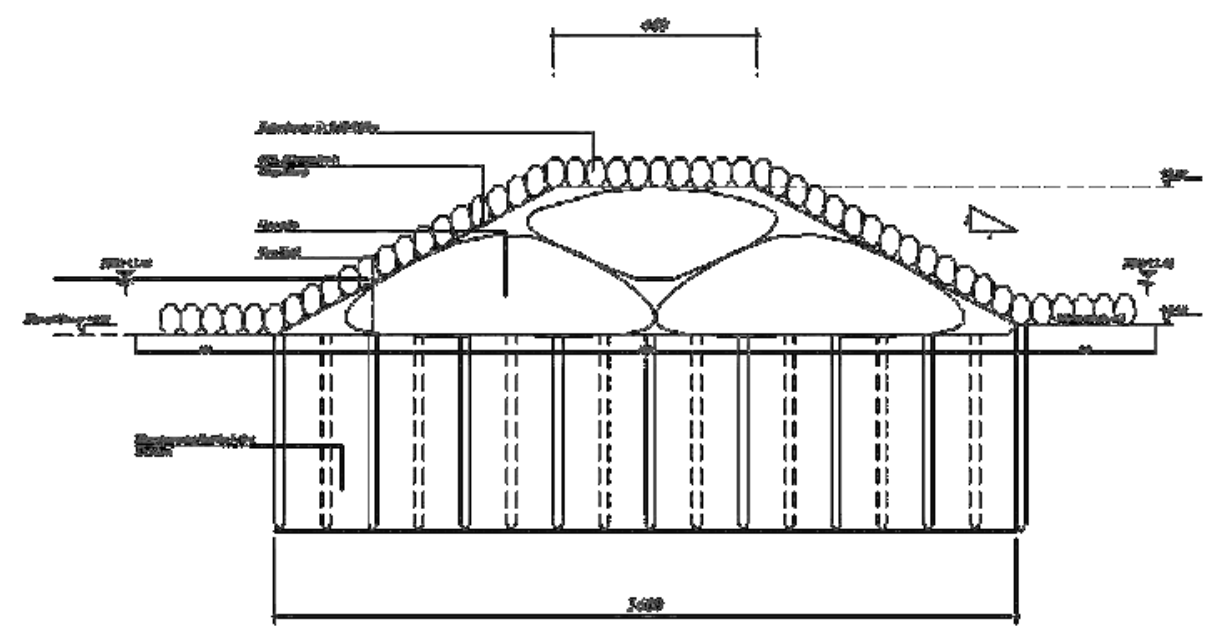

Fig.4. Typical Dike with Geotube Components [6]

\subsection{Stability of Dike Structure}

Dike construction stability requirements [10] must be calculated or analyzed for the following matters:

a. The dike body must be safe against the possibility of overflow through the lighthouse (over topping) at the planned flood discharge.

b. Based on item (a), the dike lighthouse must have a safe enough freeboard against the river water level at the planned flood discharge.

c. The height of the freeboard in item (b) must meet the applicable criterion standards such as the Indonesian National Standard (SNI).

d. The height of the dike peak on the elongated profile must be adjusted to the planned flood water level along the river as needed.

e. The slope and foot of the dike must be stable against floods, erosion and scouring. Therefore, there must be a protector. The protective layer must be adapted to the provisions in force and calculated against its economic value.

f. The dike tract must be determined as carefully as possible by considering the situation and condition of river morphology, technical and non-technical factors as well as socioeconomic conditions.

g. The distance between the dike tract and the riverbank must be enough so that if erosion or landslides occur on the riverbank, it does not affect the stability of the dike.

h. There must not be seepage and piping on the dike body.

i. There must not be seepage and piping on the dike foundation.

j. There must not be any shift in foundation due to an earthquake.

\subsection{Analytical Hierarchy Process (AHP)}

Analytic Hierarchy Process (AHP) is a method that can be used in solving problems that have many alternatives pioneered by Thomas Saaty in 1970. The stages of problem solving using the Analytic Hierarchy Process (AHP) method are as follows: 
a. Hierarchical construction

Complex problems can be more easily understood through the concept of hierarchy. In this case, the existing problems are broken down into more detailed sections. Then, the parts are arranged hierarchically, weighted and the final decision is made based on the weighting.

b. Pairwise comparisons

This pairwise comparison process uses numbers/scales that describe the level of importance of a decision element with others in the same hierarchy level. This helps decision makers compare each element of the decision because in each pairwise comparison they only concentrate on two of them.

c. Consistency

If the consistency ratio value is greater than $10 \%$, then the consideration given is too random and needs improvement. However, if the value of the consistency ratio is smaller than or equal to $10 \%$, then the consideration given can be accepted.

\section{Research Method}

This research is a research development that aims to increase knowledge about the application of decision-making methods in a construction project. In general, the stages carried out in this research are as follows:

1. Identifying to find and collect data relating to the design of dike construction.

2. Developing research questionnaires based on literature and dike project planning documents.

3. Determining research respondents

4. Distributing questionnaires and conducting in-depth interviews with the respondents

5. Processing data from the respondents and finding the geometric mean for each criterion that is compared.

6. Making a pairwise comparison for each criterion at one level

7. If the inconsistency ratio is greater than $10 \%$, then data collection will be performed. If the inconsistency ratio is smaller than $10 \%$, then it will be continued with the weighting for each element.

8. Weighting aspects, criteria and sub-criteria

9. Alternative weighting

10. Ranking aspects, criteria and sub-criteria from which the largest to the smallest of each element.

11. Ranking the alternatives that have the largest weight to the smallest of each element

The respondents of this research were various parties involved in the implementation, namely, the head of the project, site engineer, quality and quantity engineer, executor and surveyor. The criteria used are the functions and benefits, site conditions, construction costs and construction implementation. The alternative dikes used are Concrete Sheet Piles (CSP), Parapet Walls and CCSP, and landfill with geotube components. The hierarchical structure of the criteria and alternatives in the selection of the dike construction design can be seen in the following figure. 


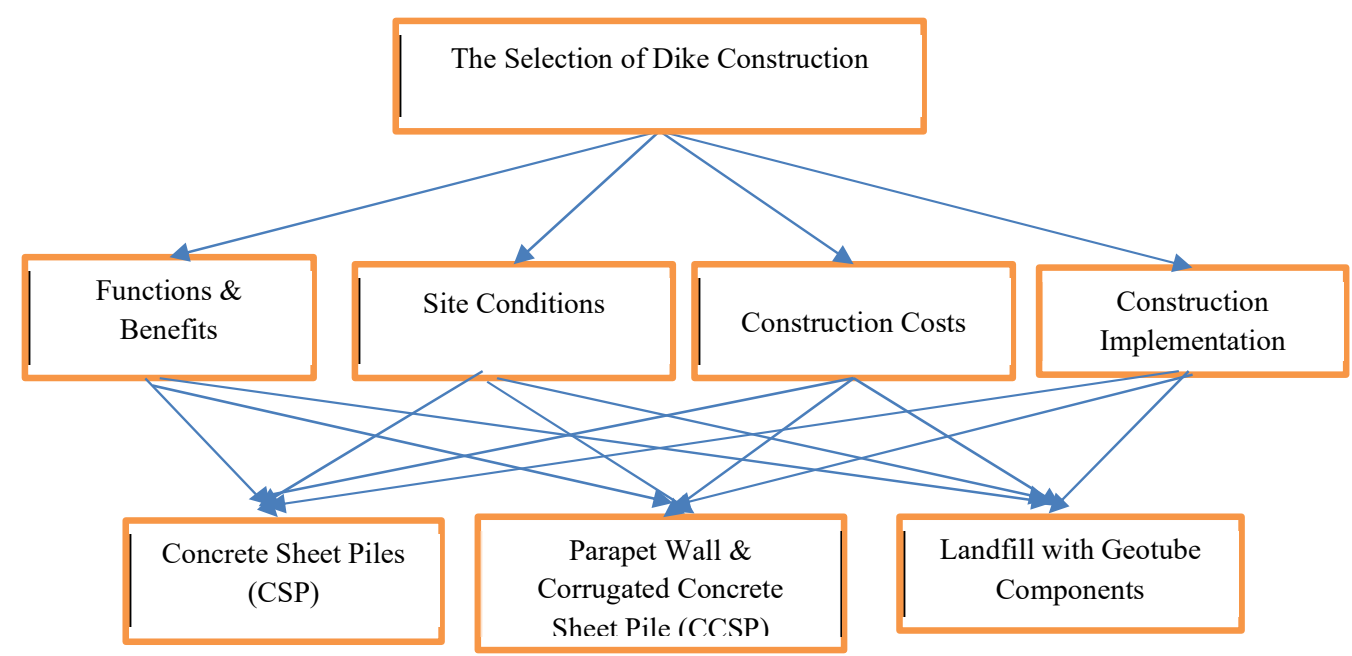

Fig. 5. Hierarchical Structure of Criteria and Alternatives

\section{Result and Discussion}

\subsection{Calculation of Consistency Test in Pairwise Comparison}

Based on the opinions of the respondents in the questionnaire, an analysis can be done to test the consistency of their answers. In the AHP method, the consistency of the paired evaluation is evaluated by calculating the Consistency Ratio (CR). If the CR value is smaller than or equal to $10 \%$, then the result of the assessment is consistent. The following are the results of the calculation of the Consistency Ratio on the criteria and alternatives used in this research.

Table 1. Value of Consistency Ratio on Criteria and Alternatives

\begin{tabular}{lcc}
\hline \multicolumn{1}{c}{ Assessment } & CR Value & Remark \\
\hline Criteria & $4 \%$ or $0.04 \%$ & Consistent \\
\hline Sub-Criteria & & \\
- Functions and Benefits & $105 \%$ or 1.05 & Inconsistent \\
- Site Conditions & $1 \%$ or 0.01 & Consistent \\
- Costs & $0 \%$ or 0.00 & Consistent \\
- Implementation & $0 \%$ or 0.00 & Consistent \\
\hline Alternative & $10 \%$ or 0.1 & \\
\hline Criteria and Sub-Criteria to & & \\
Alternative & & \\
- Functions and Benefits & & \\
- Fishing boat mooring & $2 \%$ or 0.02 & Consistent \\
- Fishing transportation lane & $1 \%$ or 0.01 & Consistent \\
- Withstand tides and waves & $0 \%$ or 0.00 & Consistent \\
- Recreational place & $0 \%$ or 0.00 & Consistent \\
- Site Conditions & & \\
- Soil type & $8 \%$ or 0.08 & Consistent \\
- Land area need & $8 \%$ or 0.08 & Consistent \\
- Dike lighthouse elevation & $0 \%$ or 0.00 & Consistent \\
- Costs & & \\
- Construction cost & $9 \%$ or 0.09 & Consistent \\
- Material cost & $4 \%$ or 0.04 & Consistent \\
- Construction Implementation & & \\
- Ease of implementation & $9 \%$ or 0.09 & Consistent \\
- Material mobilization & $1 \%$ or 0.01 & Consistent \\
- Safety from outside & $0 \%$ or 0.00 & Consistent \\
\hline$\quad$ disturbances. & & \\
\hline
\end{tabular}




\subsection{Results of Priority Weighting and Ranking Criteria for Selection of Dike Construction}

The results of weighting criteria in the selection of duke construction in flood management projects in the Tambak Lorok area in the aspects of Function and Benefits, Site Condition, Cost and Construction Implementation can be seen in Figure 6 below.

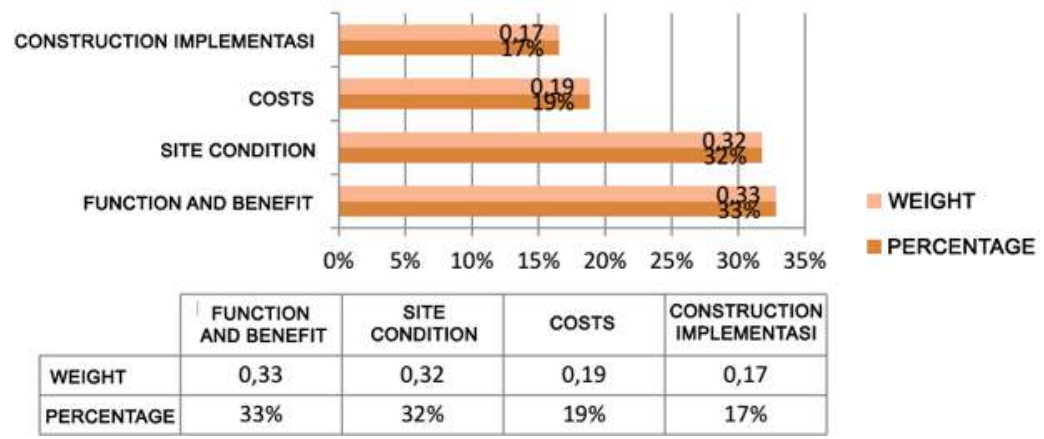

Fig.6. Criteria Weighting Chart

In evaluating the selection of criteria, the Aspect of Function and Benefits (AFB) with a weight of $33 \%$ is the most important criterion according to the respondents' assessment. Because the main function of the dike planning is to cope with floods, functions and benefits is the aspect that must be prioritized because it relates directly to security and safety for residents around the dike site. The second highest criterion is the Aspect of Site Condition (ASC) with a weight value of $32 \%$. This aspect is considered important because in the planning of a dike, a type of soil that can support the burden of the dike has a very large building and enough land area to make a dike is needed.

\subsection{Alternative Weighting Results Based on Criteria}

Based on the evaluation on 4 (four) criteria, namely functions and benefits, site conditions, construction costs and construction implementation, the three alternatives have their respective priority sequences.

\subsubsection{Alternative Priority Based on Function and Benefit Criteria}

Based on the criteria of functions and benefits, the alternative Parapet Wall with reinforced CCSP has the highest weight of.48.4\% while the alternative CSP obtains the second highest weight value of $34.6 \%$ followed by an alternative Landfill with Geotube of $17 \%$. The results can be fully seen in Figure 7.

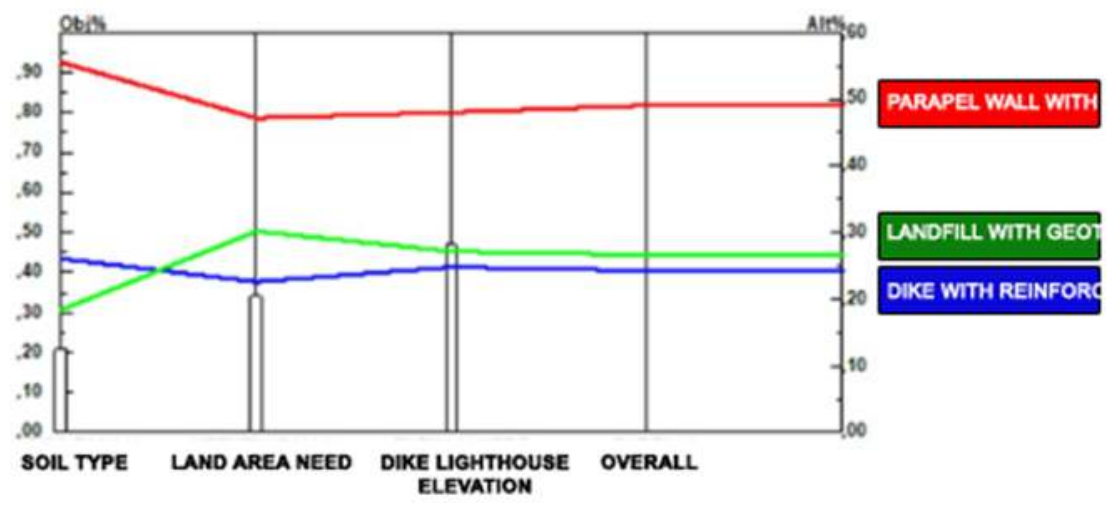

Fig. 7. Alternative Weighting Results on Function and Benefit Criteria 


\subsubsection{Alternative Priority Based on Site Condition Criteria}

Based on the criteria of site conditions, the alternative parapet wall with reinforced CCSP has the greatest weight of $49 \%$ while the second highest weight value is in the alternative of Geotube Landfill of $26.7 \%$, followed by the alternative CSP of $24.3 \%$.

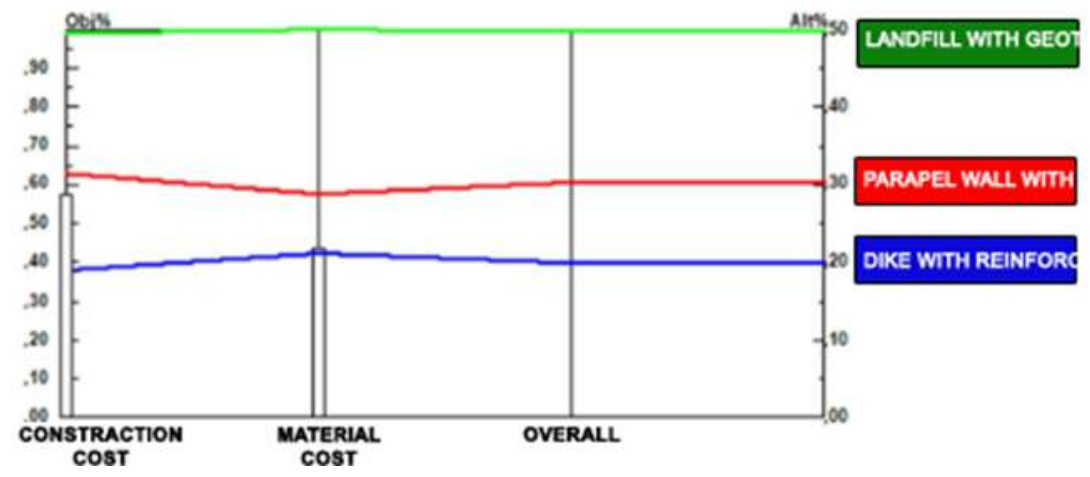

Fig. 8. Alternative Weighting Results on Site Condition Criteria

\subsubsection{Alternative Priority Based on Construction Cost Criteria}

Based on the criteria of construction costs, the alternative Geotube Landfill has the greatest weight of $49.7 \%$ while the second highest weight value is obtained by the alternative Parapet Wall with reinforced CCSP of $30.3 \%$, followed by the alternative CSP of $20 \%$.

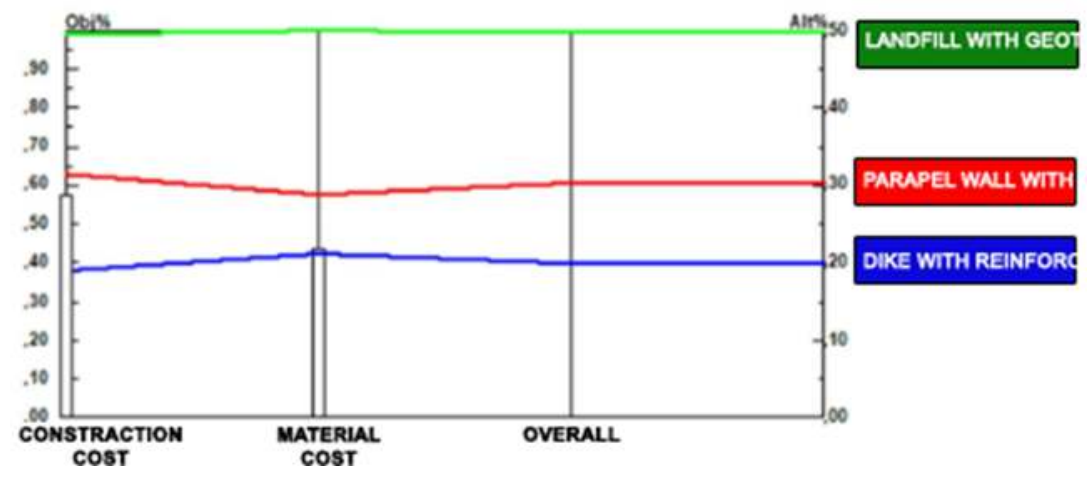

Fig. 9. Alternative Weighting Results on Construction Cost Criteria

\subsubsection{Alternative Priority Based on Construction Implementation Criteria}

Based on the construction implementation criteria, the alternative Landfill with Geotube obtains the highest value of $47.6 \%$ the alternative of the Parapet Wall with reinforced CCSP obtains $27.5 \%$, followed by the alternative CSP $25 . \%$. 


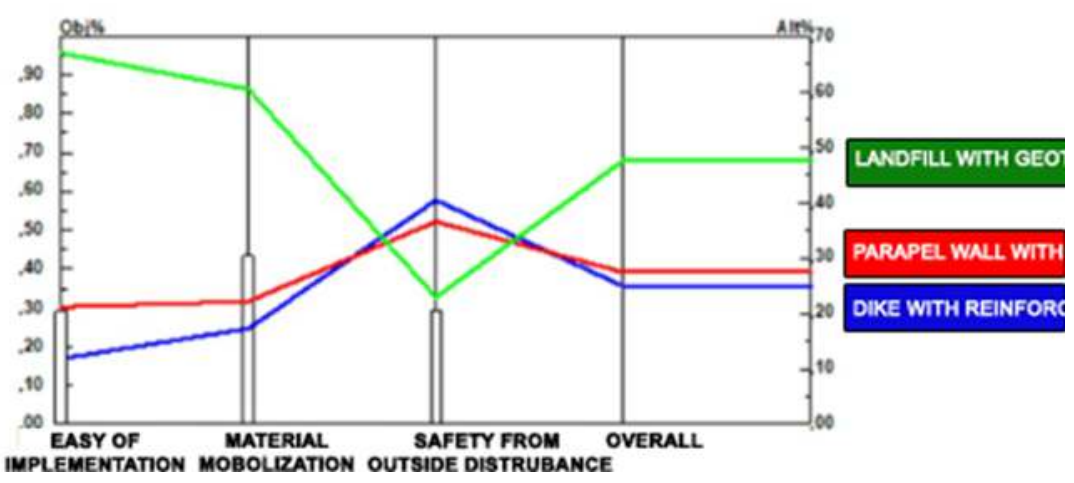

Fig. 10. Alternative Weighting Results on Construction Implementation Criteria

\subsubsection{Alternative Priority Based on Overall Criteria}

Based on the overall criteria used for the selection of dike construction, the alternative Parapet Wall with reinforced CCSP has the highest weight, which is $39.7 \%$. Then, the second highest weight is in the alternative Landfill with Geotube of $32.8 \%$. In the third place, there is an alternative CSP with the lowest weight of $27.5 \%$.

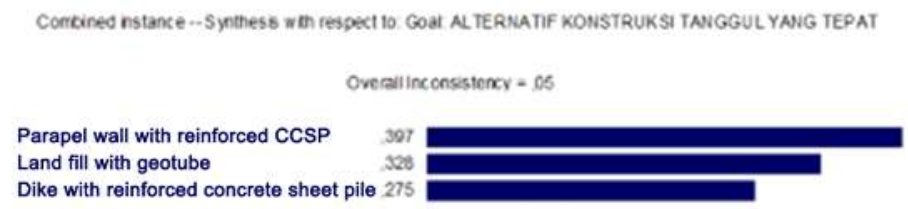

Fig. 11. Alternative Weighting Results for All Criteria

\section{Conclusion}

Based on the results of the analysis for selection of dike construction as an effort to deal with tidal floods in the Tambak Lorok area, Semarang, it can be concluded as follows:

1. Criteria consideration in determining the appropriate choice in determining the design of dike construction in Tambak Lorok, are as follows:

a. Aspect of functions and benefits which includes fishing boat mooring, fishing transportation lane, withstand tides and waves and recreational place

b. Aspect of site conditions which includes soil type, land area needs and the dike lighthouse elevation.

c. Aspect of costs which includes construction and material costs.

d. Aspect of construction implementation which includes ease of implementation, material mobilization and safety from outside disturbances.

2. The analysis using the AHP method results in weighting value of criteria with priority order criteria of Function and Benefits (33\%), Site Conditions (32\%), Costs (18\%) and Construction Implementation (17\%).

3. The dike construction priority analysis based on weighting on all criteria obtained priority results in the order as follows: Parapet wall with Corrugated Concrete Sheet Pile (CCSP) reinforcement of $39.7 \%$, Landfill with Geotube Components of $32.8 \%$ and Concrete Sheet Piles (CSP) of $27.5 \%$. 


\section{Acknowledgment}

The authors are grateful for the financial support and other supports of this research provided by Research and Community Service Board (LPPM) and Civil Engineering Department of Sultan Agung Islamic University, Indonesia.

\section{References}

[1] H. P. Adi and S. I. Wahyudi, Tidal Flood Handling through Community Participation in Drainage Management System (A case study of the first water board in Indonesia), International Journal of Integrated Engineering, Vol. 10, pp. 19-23, 2018.

[2] Achmad Wibriyan Fitriansyah, Calculation Analysis Method for Slope Stability Using The Sheet Pile Strength Using The Geotructutal Anaysis Version 19, 2017.

[3] D. Yudianto, Evaluation of Vacum Capacity and Post Disposal Responses in Residential Area ,Albert. 2013.

[4] S. I. Wahyudi, H. P. Adi, A. Rochim, and D. Marot, Aspects of Hydrology, Tidal and Water Storage Capacity For Simulating Dike Model of Channel and Retention Basin, Journal of Civil and Environmental Engineering IJCEE/IJENS Volume 14, Issue 5, ISSN : 2077-1258,

[5] M. Fitri Herawaty, Analysis of Groundwater Flow Distribution Patterns on the Embankment Model, Jurnal Rona Tek. Pertanian., 2014.

[6] N. Swan, Sea Wave Simulation in the Design of the Sea Dike, Program Studi Sarjana Ilmu Komputasi Fakultas Informatika Universitas Telkom Bandung, vol. 6, no. 1, pp. 2557$2575,2019$.

[7] A. Binilang and E. M. Wuisan, The study of the high effectiveness of the flood embankment in Simbel Village, West Kakas District, Minahasa Regency, vol. 4, no. 2, 2016.

[8] R. Sanggawuri et al., Evaluation of The Use of Non Dike Method and Packing Terminal in Tanjungmas Port, vol. 5, pp. 262-274, 2016.

[9] I. S. Ferryandi, Ari Sandhyavitri, Physical Model of Full Scale of Dike Construction and Tidal Gate on The Effect of Coverage of Tidal Flood in Coconut Plantation Based on Local Wisdom (Case Study of Gaung Anak Serka Subdistrict), Selodang Mayang, 2018.

[10] Maizir, Analysis of Revetment as River Protection in Flood Control Effort (case study on Sungai Batang Mangor, Padang Regency), J. Tek. Sipil ITP, vol. 3, no. 2, 2016. 